\title{
PETROLOGY OF THE RENARD IGNEOUS BODIES: HOST ROCKS FOR DIAMOND IN THE NORTHERN OTISH MOUNTAINS REGION, QUEBEC
}

\author{
T. C. Birkett ${ }^{1}$, T.E. McCandless ${ }^{2}$, C. T. $\operatorname{Hood}^{2}$ \\ ${ }^{1}$ SOQUEM INC., Sainte-Foy, Quebec, Canada \\ ${ }^{2}$ Ashton Mining of Canada Inc., North Vancouver, B.C., Canada
}

\section{INTRODUCTION}

The Superior Craton hosts a wide variety of mantlederived igneous rocks. These include kimberlite (Kong et al. 1999), melnoite (e.g. alnoite, aillikite; Digonnet 1997, Digonnet et al. 2000; melilitite, Dimroth, 1970) and ultramafic lamprophyre. Diamondiferous kimberlitic bodies were discovered by the Ashton-SOQUEM joint venture in late 2001 after geophysical follow-up of favourable kimberlite indicator mineral dispersions in the northern Otish Mountains. Renard 1 and 2 were confirmed as diamond-bearing in that same year, and an additional six distinct bodies were discovered in 2002, all of which contain diamond. In this study, textural, mineralogical and geochemical features are used to evaluate the petrogenesis of these rocks, which share features common to both kimberlite and melnoite.

\section{REGIONAL GEOLOGY}

The Renard bodies were emplaced into metamorphic rocks of the Superior Province, comprised of local basement gneiss, regional greenstone belts, diabase dykes of the $2.5 \mathrm{Ga}$ Mistassini dyke swarm, and Paleoproterozoic sedimentary rocks of the Otish Supergroup. At present, only large-scale geological mapping has been completed (Hocq 1985). Basement gneiss near the Renard bodies is believed to have been metamorphosed at upper amphibolite to lower granulite facies conditions in late Archean time.

\section{GEOLOGY OF THE IGNEOUS BODIES}

\section{FORM AND FACIES DIVISION}

In plan view the Renard bodies exhibit irregular to elongate forms, based on limited drilling. In cross-section the bodies are steep-sided breccia pipes surrounded by breccia zones in peripheral country rock. Both diatremefacies kimberlite and wallrock are intruded by variable amounts of hypabyssal-facies kimberlite as dykes and/or sills.
Hypabyssal rocks are distinguished by common to abundant disseminated calcite as determined by reaction to dilute $\mathrm{HCl}$. Country rock xenoliths are rare, but olivine macrocrysts are ubiquitous with some reaching several centimetres in longest dimension. Uniform-textured groundmass is the norm in these rocks, although segregationary-textured groundmass is locally present in the larger bodies.

Diatreme facies rocks are breccias, with little or no calcite as determined by a lack of reaction to dilute $\mathrm{HCl}$. Pelletal lapilli with kernels of macrocrystic olivine or xenoliths of crustal rock are present throughout diatreme facies units, though rarely more abundant than a few percent. For this reason it is appropriate to describe the Renard breccias as TKB (tuffisitic kimberlite breccia) without implying a formal facies assignment.

Renard bodies were emplaced in gneiss and tonalite host rocks, which consist largely of gneisses of intermediate composition with the common mineral assemblage $\mathrm{Pl}+$ Bt + Opx + Qtz (symbols follow Kretz 1983). Bands of tonalite gneiss up to several metres wide are also widespread, as are medium to coarse-grained nondeformed granite dykes that intrude the gneissic rocks. Collectively these units comprise the country rock xenolith population in the breccias, in amounts ranging from 15 to 90 percent of the total rock volume.

Wallrock breccias peripheral to some bodies are formed of these same units, though extensively brecciated with a matrix of comminuted mineral fragments and without a detectable kimberlitic component. Grain size reduction in some zones has produced rocks with the appearance of an arkose at the macroscopic scale.

\section{PetrographIC CHARACTERISTICS}

In thin section, hypabyssal facies rocks have relatively simple mineralogy and texture. Macrocrysts of subhedral to anhedral olivine are dispersed in a groundmass of ilmenite, spinel, perovskite, Ti-magnetite - ulvospinel, phlogopite and apatite in a mesostasis dominantly of calcite. Partially to completely serpentinised secondgeneration olivine is also observed, as is monticellite. Atoll-textured spinels are common and locally abundant. 
Necklace texture is present, though rare and of limited development. Plates of the phlogopite - kinoshitalite series poikilitically enclose groundmass monticellite, perovskite, apatite, and iron oxides.

Breccias have more complex mineralogy, with olivine macrocrysts, commonly serpentinised and in some examples rimmed by groundmass diopside in a mesostasis of phlogopite and serpentine. The earliest groundmass is medium to dark brown, weakly magnetic, with a small amount of calcite present. This groundmass is replaced, commonly with obliteration of textures such as lapilli, by a medium to pale green groundmass, slightly more granular in appearance, non-magnetic, with no detectable calcite. The groundmass recrystallisation may be due to low - temperature processes, possibly post emplacement.

\section{MINERALOGY AND MINERAL CHEMISTRY}

\section{Olivine}

Magnesian olivine is an abundant component of all Renard kimberlites. Macrocrysts and their serpentinised pseudomorphs are ubiquitous. Serpentine after groundmass olivine is common to all facies. Macrocrysts are typically $2 \mathrm{~cm}$ or less in length, rounded, although a few up to $4 \mathrm{~cm}$ have been noted. A few mantle-derived nodules of olivine with orthopyroxene, clinopyroxene or garnet have been observed. Olivine analyses are limited to macrocryst cores because of serpentinisation, and range from $\mathrm{Fo}_{88}$ to $\mathrm{Fo}_{93}$ with few outliers. $\mathrm{CaO}$ is low at 0.01 to 0.1 weight $\% ; \mathrm{Cr}_{2} \mathrm{O}_{3}$ is also low at less than 0.1 weight $\%$. Concentrations of $\mathrm{MnO}$ are near 0.1 weight $\%$, and $\mathrm{NiO}$ varies from 0.3 to 0.4 weight $\%$.

\section{Monticellite}

Monticellite is present as small subhedral crystals in the groundmass of some hypabyssal facies samples. Microanalyses return low $\mathrm{NiO}$ contents, less than 0.1 weight $\%$ and relatively high $\mathrm{MnO}$ at 0.2 to 0.3 weight $\%$. Contents of $\mathrm{Cr}_{2} \mathrm{O}_{3}$ are low, commonly not detected.

\section{Phlogopite}

Phlogopites from hypabyssal facies samples show variable compositions from Ba-phlogopite - kinoshitalite to tetraferriphlogopite. There are a number of phlogopite compositions that warrant further consideration as they plot within, and away from, compositional trends attributed to igneous rocks related to kimberlite (Figures 1, 2). Samples from the least-contaminated rocks display iron-rich cores with development of iron-poor mantles followed in a few cases with red tetraferriphlogopite rims rich in iron but depleted in $\mathrm{Al}$ and Ti. This pattern of initial iron depletion is typical of kimberlite but distinct from other potassic ultramafic rocks. Aluminium in phlogopite commonly increases slightly during crystallisation, but in some cases decreases slightly.

\section{Phlogopite}

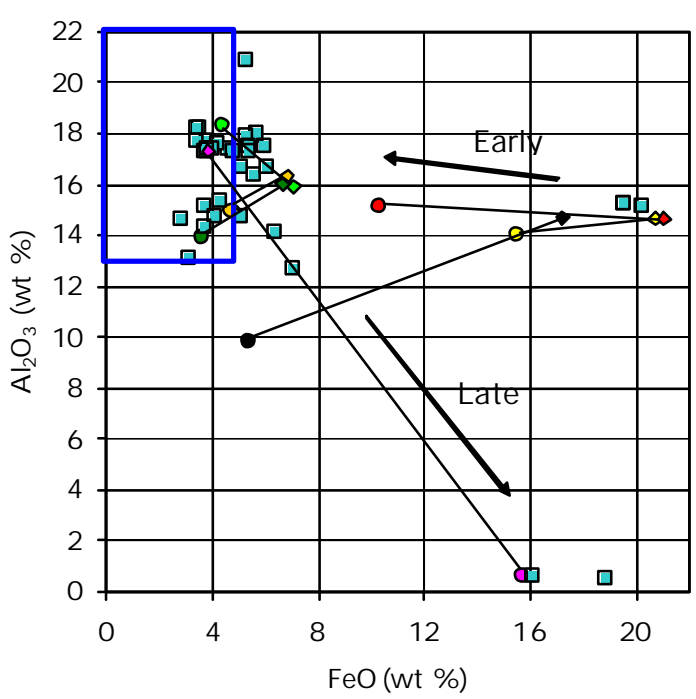

Figure 1: Phlogopite compositions in the space $\mathrm{FeO}_{\mathrm{T}}-$ $\mathrm{Al}_{2} \mathrm{O}_{3}$. Diamonds and circles indicate analyses of cores and rims of individual crystals. The blue box outlines the field of kimberlite groundmass phlogopite (Mitchell 1997)

Phlogopite

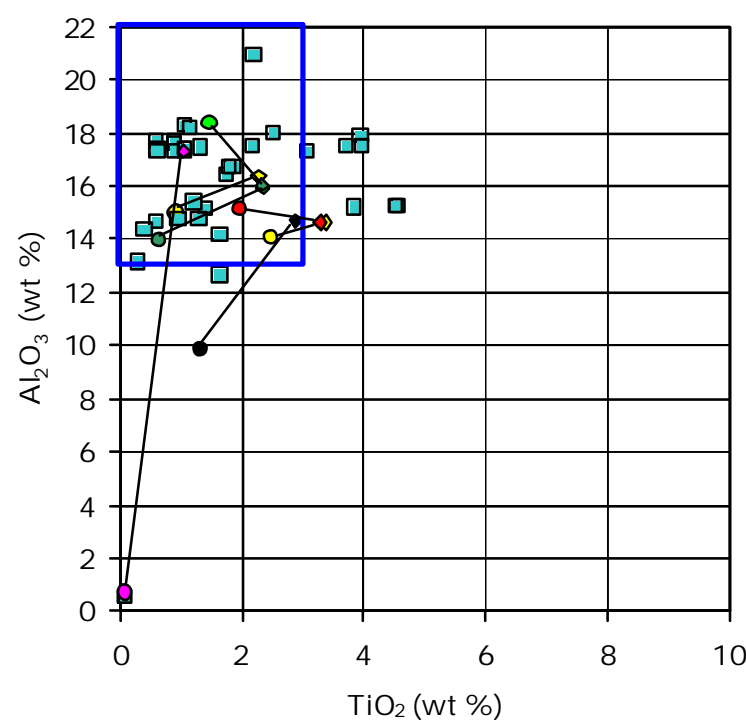

Figure 2: Phlogopite compositions in $\mathrm{TiO}_{2}-\mathrm{Al}_{2} \mathrm{O}_{3}$ space. Diamonds and circles indicate analyses of cores and rims of individual crystals. The blue box outlines the field of kimberlite groundmass phlogopite (Mitchell, 1997). 


\section{IImenite}

As distinct from ilmenite xenocrysts, rare groundmass ilmenite forms small, spongy grains of corroded aspect. Compositionally, ilmenite is high $\mathrm{MnO}$ (13 to 16 weight $\%)$ with a relatively high ferric iron component and low $\mathrm{Ti}$ and $\mathrm{Mg}$. These compositions differ from the strongly magnesian ilmenite typical of kimberlite groundmass. It is possible that the compositions are residual to a latemagmatic reaction, though initial observations are insufficient to establish this with certainty.

\section{Apatite}

Texturally, apatite forms radiating splays of groundmass crystals associated with serpentine and calcite. Compositionally, it is low in total rare earth content, with light rare earth oxides typically less than $0.5 \%$ for La to $\mathrm{Sm}$. In contrast, strontium contents cover a wide range, from 0.1 to 2.9 weight $\% \mathrm{SrO}$, although the majority is less than $1 \%$. These compositional features are at odds with groundmass apatite in kimberlite and melnoite, both of which have low REE and low Sr.

\section{Spinel}

Although atoll textures observed are typical of spinel from kimberlite, the cores are aluminous picro-chromite with 8 to $10 \% \mathrm{Al}_{2} \mathrm{O}_{3}, 13$ to $15 \% \mathrm{MgO}$, and 52 to $56 \%$ $\mathrm{Cr}_{2} \mathrm{O}_{3}$. Contents of $\mathrm{TiO}_{2}$ are low at 2 to $4 \%$, and $\mathrm{MnO}$ is generally not detected. Some crystals show chemical zonation from Ti-poor, Cr-rich cores to Ti-rich, Al-rich rims. Later-crystallising spinels are largely Ti-poor magnesioferrite - magnetite. The aluminous spinel compositions are atypical for kimberlite, melnoite, and related igneous rocks.

\section{Perovskite}

Perovskite is a common groundmass mineral, occurring as small subhedral to subrounded dark brown crystals. With respect to some elements, it is typical of kimberlite (and orangeite) with moderate $\mathrm{ThO}_{2}$ ( 0 to $\left.1 \%\right), \mathrm{Nb}_{2} \mathrm{O}_{5}$ (0.6 to $1.9 \%$ ), REE (3.4 to $6.1 \% \mathrm{La}_{2} \mathrm{O}_{3}$ to $\mathrm{Sm}_{2} \mathrm{O}_{3}$ ) and $\mathrm{Na}_{2} \mathrm{O}$ $(0.2$ to $0.44 \%)$. In terms of strontium, most grains have contents near $0.2 \%$, although analyses from two samples show unusually high SrO near 1 weight $\%$. The higher $\mathrm{SrO}$ contents are atypical for perovskite from kimberlite and melnoite.

\section{Xenocryst Minerals}

The Renard bodies were discovered after follow-up of indicator minerals with favourable mineral chemistry were discovered in till samples. Xenocryst minerals consist of ilmenite, chromian spinel, forsterite, aluminous enstatite, chromian clinopyroxene, and chromian pyrope, the latter of which has a subcalcic composition supporting the likely presence of diamond in the igneous host.

All of the Renard bodies are diamond-bearing, with diamond contents up to 1.3 carats per tonne (lower size limit $0.85 \mathrm{~mm}$ in a square mesh sieve). Estimated diamond contents are presently based on small samples (up to five tonnes) which are insufficient to represent actual grades.

\section{DISCUSSION}

Mitchell (1995a, 1997) proposes that electron-probe microanalysis of groundmass phlogopite is a useful criteria for lamprophyric rock classification, with total iron, $\mathrm{TiO}_{2}$ and $\mathrm{Al}_{2} \mathrm{O}_{3}$ which as the useful discriminants (Mitchell, 1995). Phlogopite from the Renard bodies supports classification as kimberlite, with most analyses falling within the specified compositional region (Figure 1,2). However, monticellite is present in both kimberlite and melnoite, and aluminous biotite is present only in melnoite (Figure 1). Other mineral compositions and textures do not fit either a melnoite or kimberlite classification, such as aluminous spinel compositions, Srrich apatite and perovskite, and Mn-ilmenite.

With respect to the groundmass spinels, atoll-texture is the common textural expression in kimberlite, and is typically absent in other related rocks. The Renard bodies contain atoll-textured spinel, which in some cases have the $\mathrm{Mg}-\mathrm{Cr}$ rich compositions. However many spinels deviate and are more aluminous than accepted for kimberlite, orangeite, melnoite or lamproite (Mitchell, 1995a, 1997).

Macroscopic and thin section examination reveals extensive interaction between the Renard magmas and their host rocks. Diatreme facies breccias commonly contain 50 volume percent of country rock and mineral fragments. Most rock fragments are subangular to subrounded, but a population of well-rounded rock fragments is also observed. In many areas, visual evidence of crustal xenolith and host magma interaction can be observed. Broken mineral grains are common and feldspar cleavage fragments are significant groundmass components, which when reacted commonly show concentric reaction bands. Rock fragments observed in thin section are converted to assemblages of carbonate, serpentine, sericite and chlorite. Mafic minerals in the crustal xenoliths have typically strongly reacted with the magma; of these garnet reacts most and biotite least. Liberated subhedral crystals of biotite are commonly dispersed in breccia groundmass to the extent that they are indistinguishable at the hand sample scale. In thin section, the grains display identical pleochroism with those of xenoliths of crustal derivation and are interpreted as locally derived xenocrysts. Efficient disaggregation and 
assimilation of country rock units into the Renard magmas may have contributed to difficulties in assigning these rocks to a strictly kimberlite or melnoite classification.

From an economic perspective, an igneous host is required only to pick up sufficient numbers of quality diamonds, and bring them to the surface post-haste. Diamond explorationists have searched for kimberlite for the last 130 years, only to be told (by academics) that some diamond mines are actually in lamproites or orangeites. While more diamond mines are in kimberlite than in orangeite or lamproite, , these minority rock types are difficult to exclude when diamond mines such as Argyle (>6cts/tonne; lamproite) and Swartruggens (5$15 \mathrm{cts} /$ tonne; orangeite) comprise part of the population.

For diamond exploration, it is useful to have a general term to describe all potential igneous host rocks for diamond. Nearly all such rocks share similarities. For example, all have sampled similar parts of the mantle in their ascent. Anhedral olivine macrocrysts are a common feature, which impart a porphyritic texture. Some or all of the mantle indicator assemblage is present, such as picroilmenite, pyrope garnet, chrome diopside, and/or picrochromite. Recovery of microscopic diamonds from kilogram-sized samples of an igneous host rock is further support that the magma has sampled diamond-bearing mantle. As each of these criteria is met, the rock continues to share characteristics with kimberlite. It is suggested that rocks of this nature be described as 'kimberlitic' in an exploration program, and classified along academic guidelines at a point when such research is justified.

After ten years of active diamond exploration in the Slave craton, nearly 300 igneous host rocks have been discovered and identified as kimberlite. The Superior craton, roughly ten times larger than the Slave, has been explored for diamonds for over 30 years, with fewer than 100 igneous host rocks for diamond discovered, of which at least two types are not typical kimberlite (e.g., aillikite, 'wawaite'). It is premature to assume that a mantlederived igneous rock can be excluded from economic assessment because it is not kimberlite sensu stricto. Diamond contents up to 1.3 carats per tonne in Renard bodies justify further economic investigation of these rocks, regardless of their genetic classification.

\section{REFERENCES}

Digonnet, S., 1997. A petrogeochemical study of kimberlites from the Torngat Mountains, New Quebec (in French).
Unpublished M.Sc. thesis, University of Quebec, Montreal.

Digonnet, S., Goulet, N., Bourne, J., Stevenson, R. and Archibald, D. 2000. Petrology of the Abloviak dykes, New Quebec: evidence for a Cambrian diamondiferous alkaline province in northeastern North America. Can. J. Earth Sci. 37, 517-533.

Dimroth, E., 1970. Meimechites and carbonatites of the Castignon Lake Complex, New Quebec. Neues Jahrbuch für Petrologie und Mineralogie, Abhandlungen 130, 247274.

Hocq, M., 1985. Géologie de la région des Lacs Campan et Cadieux. Ministère de l'énergie et des ressources (Québec) ET 83-05, 178 p.

Kong, J.M., Boucher, D.R. \& Scott Smith, B.H., 1998 Exploration and Geology of the Attawapiskat Kimberlites, James bay Lowland, Northern Ontario, Canada. In: Gurney, J.J., Gurney, J.L., Pascoe, M.D., Richardson, S.H. (Eds), Proceedings of the $7^{\text {th }}$ International Kimberlite Conference. University of Cape Town, Cape Town, 452-467.

Kretz, R. 1983. Symbols for rock-forming minerals. Am. Mineral. 68, 277-279

Mitchell, R.H., 1995a. The role of petrography, lithogeochemistry in exploration for diamondiferous rocks. In: Griffin W.L. (Ed), Diamond Exploration: Into the 21st Century. J. Geochem. Explor., 53, 339-350.

Mitchell, R.H., 1995b. Kimberlites, Orangeites and Related Rocks. Plenum Press, New York.

Mitchell, R.H., 1997. Kimberlites, Orangeites, Lamproites, Melilitites, and Minettes: A Peterographic Atlas. Almaz Press Inc,. Thunder Bay, Ontario, 243p.

Mitchell, R.H., Scott Smith, B.H. \& Larsen, L.M., 1999. Mineralogy of Ultramafic Dikes from the Sarfartoq, Sisimiut and Maniitsoq Areas, West Greenland. In: Gurney, J.J., Gurney, J.L., Pascoe, M.D., Richardson S.H. (Eds), Proceedings of the $7^{\text {th }}$ International Kimberlite Conference, University of Cape Town, Cape Town, 574-583.

O'Brien, H.E. and Tyni, M., 1999. Mineralogy and geochemistry of kimberlites and related rocks from Finland... In:_Gurney, J.J., Gurney, J.L., Pascoe, M.D., Richardson S.H. (Eds), Proceedings of the $7^{\text {th }}$ International Kimberlite Conference, University of Cape Town, Cape Town, pp. 625-636.

Rock, N.M.S., 1991. Lamprophyres. Blackie, Glasgow, U.K. 